Research Article

\title{
Transvaginal Ultrasound Assessment of Cervical Length in Threatened Preterm Labor
}

\section{Penilaian Panjang Serviks pada Ancaman Persalinan Preterm Menggunakan Ultrasonografi Transvaginal}

\section{Prasila Ekaputri, Nuswil Bernolian, Hatta Ansyori, Azhari, Syarif Husin}

Department of Obstetrics and Gynecology

Faculty of Medicine University of Sriwijaya/

Dr. Mohammad Hoesin General Hospital

Palembang

\begin{abstract}
Objectives: To determine the cut off point of cervical length using transvaginal ultrasonography to predict the actual occurrence of preterm labor in women with threatened preterm labor.

Methods: A cross sectional study with consecutive random sampling method. We examined 80 women with singleton pregnancy complaining of regular, painful uterine contraction and ruptured membrane at 24-36 weeks of gestation. Women in active labor, defined by the presence of cervical dilatation $\geq 3 \mathrm{~cm}$, and having complication were excluded. When the patient was admitted, a transvaginal scan was performed to measure the cervical length. Parenteral magnesium sulfate was given as the subsequent management. The primary outcome was delivery within 24 hours of presentation.

Results: We found that the optimal cut off values for cervical length was $2.65 \mathrm{~cm}$ with sensitivity $94.4 \%$, specificity $65.4 \%$, positive predictive value $75.4 \%$ and negative predictive value $81.8 \%$. In 69 cases, the cervical length was $>2.65 \mathrm{~cm}$, with 52 patients successfully continued their pregnancy until more than 24 hours. In the 11 cases with cervical length $\leq 2.65 \mathrm{~cm}$, delivery within 24 hours occurred in 9 cases $(81,8 \%)$.

Conclusion: The findings of this study suggest that in women with threatened preterm labor, cervical length $\leq 2.65 \mathrm{~cm}$ may help predict the actual occurrence of preterm labor.

[Indones J Obstet Gynecol 2012; 36-2: 81-4]

Keywords: cervical length, threatened preterm labor, transvaginal ultrasonography
\end{abstract}

\begin{abstract}
Abstrak
Tujuan: Untuk mengetahui nilai potong dari panjang serviks menggunakan ultrasonografi transvaginal untuk memperediksi terjadinya persalinan preterm pada perempuan dengan ancaman persalinan preterm.

Metode: Penelitian ini merupakan studi pontong lintang dengan metode pengambilan sampel berupa consecutive sampling. Semua perempuan hamil tunggal dengan ancaman persalinan preterm pada usia kehamilan 24-36 minggu masuk ke dalam penelitian ini. Kriteria eksklusi adalah perempuan hamil dalam fase aktif dan memiliki komplikasi obstetri atau medis. Pada perempuan dengan ancaman persalinan pretem dilakukan ultrasonografi transvaginal saat dirawat di rumah sakit, kemudian pasien mendapat terapi tokolitik magnesium sulfat parenteral. Luaran yang dinilai adalah kelahiran dalam waktu 24 jam.

Hasil: Nilai potong panjang serviks yang optimal untuk memprediksi terjadinya persalinan preterm adalah 2,65 $\mathrm{cm}$ dengan sensitivitas $94,4 \%$, spesifisitas $65,4 \%$, nilai ramal positif $75,4 \%$ dan nilai ramal negatif $81,8 \%$. Pada 69 kasus dengan panjang serviks $>2,65 \mathrm{~cm}$ terdapat 52 pasien yang berhasil mempertahankan kehamilannya lebih dari 24 jam sedangkan pada 11 kasus dengan panjang serviks $\leq 2,65 \mathrm{~cm}$, terjadi kelahiran dalam waktu kurang dari 24 jam pada 9 kasus $(81,8 \%)$.
\end{abstract}

Kesimpulan: Panjang serviks $\leq 2,65 \mathrm{~cm}$ dapat digunakan untuk memperkirakan terjadinya persalinan preterm pada perempuan dengan ancaman persalinan preterm.

[Maj Obstet Ginekol Indones 2012; 36-2: 81-4]

Kata kunci: ancaman persalinan preterm, panjang serviks, ultrasonografi transvaginal

Correspondence: Prasila Ekaputri. Department of Obstetrics and Gynecology. Faculty of Medicine University of Sriwijaya/ Dr. Mohammad Hoesin Hospital, Palembang. Mobile phone: 08127811942. Email: prasilaputri@gmail.com

\section{INTRODUCTION}

Preterm delivery is the leading cause of neonatal mortality and morbidity. ${ }^{1}$ In the UK, the incidence of preterm birth was $12 \%$ in $2001 .^{2}$ The use of tocolytics in threatened preterm labor had no significant effect to suppress premature labor. ${ }^{3}$

Premature infants are at greater risk of suffering short and long term complications. Significant progress has been made in the care of premature in- fant, but not in the early detection of preterm labor. ${ }^{1,4}$ Preterm labor can be diagnosed using traditional and transvaginal ultrasonography method by measuring the cervical length. The diagnosis using traditional method has low sensitivity and specificity rates, while transvaginal ultrasonography measurement of cervical length has been proven to be more accurate in predicting preterm labor. ${ }^{5-13}$ 
Transvaginal ultrasonography method can be used to produce clear image for cervical length measurement; the image quality was not affected by intestine, obesity and abdomen scar so the obstetrician can measure the cervical length more accurately. ${ }^{5-13}$

\section{METHOD}

We performed a cross sectional study with consecutive random sampling method. We examined 80 women with singleton pregnancy complaining of regular, painful uterine contraction and ruptured membrane at 24-36 weeks of gestation. The gestation was calculated based on the menstrual pregnancy. Women in active labor, defined by the presence of cervical dilatation $\geq 3 \mathrm{~cm}$ and those with obstetrics and medical complication were excluded. The study was carried out at Dr. Moh Hoesin General Hospital Palembang during February - December 2010. Written informed consent was obtained from the women agreeing to take part in this study, which was approved by the research ethics committee of Dr. Mohammad Hoesin General Hospital Palembang.

Transvaginal ultrasonography measurement was performed by a fetomaternal consultant to assess the cervical length of the women in admission. An Aloka Pro Sound SSD 3500 Plus ultrasonography was used. Three measurements were obtained and the shortest length was recorded. Parenteral magnesium sulfate was given by attending obstetricians as the subsequent therapy. The primary outcome was delivery within 24 hours of presentation.

We collected the demographic characteristics of the women under study such as maternal age, gestational age, parity, and previous preterm birth history. To determine the cut off point for cervical length, we constructed a receiver-operator characteristics curve. The risk of preterm delivery according to the result of transvaginal ultrasonography was determined by estimating the odd ratio with their 95\% confidence interval. The means were compared with the Student $\mathrm{t}$ test.

\section{RESULTS}

Table 1 shows the general characteristics of the population of this study. Out of 80 patients, 54 patients successfully continued their pregnancy - a prevalence success rate of $67.5 \%$. All patients have no history of previous preterm birth. They were hospitalized and received parenteral tocolytics magnesium sulfate.

Table 1. General Characteristics of the Subjects

\begin{tabular}{lc}
\hline \hline \multicolumn{1}{c}{ Maternal age (year) (mean \pm SD) } & $\mathbf{2 7 . 0 8} \pm \mathbf{5 . 7 7}$ \\
\hline Gestational age (week) (mean \pm SD) & $30.26 \pm 4.19$ \\
Parity (\%) & \\
- Nulliparity & $60(48 / 80)$ \\
- Primiparity & $13.8(11 / 80)$ \\
- Multiparity & $3.8(3 / 80)$ \\
Body Mass Index (\%) & \\
- 18.5 - 25 & $63(78 \%)$ \\
- $>25$ & $17(21.2 \%)$ \\
\hline \hline
\end{tabular}

We classified the patients into two groups: the successful tocolytics group, consisting of patients who continue the pregnancy for longer than 24 hours, and the unsuccessful tocolytics group, consisting of patients who proceed with delivery within 24 hours after the parenteral tocolytics magnesium sulfate was administered. Based on the measurement of cervical length, the successful tocolytics group has longer cervix than the unsuccessful tocolytics group. The relation between cervical length and the tocolytics group is shown in Table 2 .

Table 2. Comparison of the Cervical Length between the Successful and Unsuccessful Tocolytics Group

\begin{tabular}{lccc}
\hline \hline \multirow{2}{*}{ Variable } & \multicolumn{2}{c}{ Tocolytics Group } & \multirow{2}{*}{ p } \\
\cline { 2 - 3 } & Successful & Unsuccessful & \\
\hline Cervical length $(\mathrm{cm})$ & $3.92 \pm 0.76$ & $2.81 \pm 0.31$ & 0.001 \\
Range min-max $(\mathrm{cm})$ & $2.60-5.50$ & $2.50-3.60$ & \\
\hline \hline
\end{tabular}

We used receiver-operator characteristics (ROC) curve to analyze the cervical length. The analysis result showed the best combination of sensitivity and specificity of our diagnostic test to determine whether cervix length can predict preterm labor.

The cut off point of cervical length in determining the success of tocolytics administration to suppress premature labor was $2.65 \mathrm{~cm}$ as displayed in Table 3. There was significant relationship between cervical length and preterm labor incident (p : 0.001) with odd ratio of 13.76 . 
Table 3. Cut off point of Cervical Lenght in Determining The Successful Tocolytics Administration

\begin{tabular}{|c|c|c|c|c|c|c|c|c|c|c|c|c|}
\hline \multirow{3}{*}{$\begin{array}{l}\text { Cervical } \\
\text { Length Cut off } \\
\text { Point (cm) }\end{array}$} & \multicolumn{4}{|c|}{ Tocolytic administration status } & \multicolumn{2}{|c|}{ Total } & \multirow{2}{*}{ SSV } & \multirow{2}{*}{ SPF } & \multirow{2}{*}{ NRP } & \multirow{2}{*}{ NRN } & \multirow{3}{*}{$\mathbf{p}$} & \multirow{3}{*}{ OR } \\
\hline & \multicolumn{2}{|c|}{ Successful } & \multicolumn{2}{|c|}{ Unsuccessful } & \multirow[b]{2}{*}{$\mathbf{n}$} & \multirow[b]{2}{*}{$\%$} & & & & & & \\
\hline & $\mathbf{n}$ & $\%$ & $\mathbf{n}$ & $\%$ & & & (\%) & (\%) & (\%) & $(\%)$ & & \\
\hline$>2.65$ & 52 & 75.4 & 17 & 24.6 & 69 & 100.0 & 94.4 & 65.4 & 75.4 & 81.8 & 0.001 & 13.76 \\
\hline$\leq 2.65$ & 2 & 18.2 & 9 & 81.8 & 11 & 100.0 & & & & & & \\
\hline
\end{tabular}

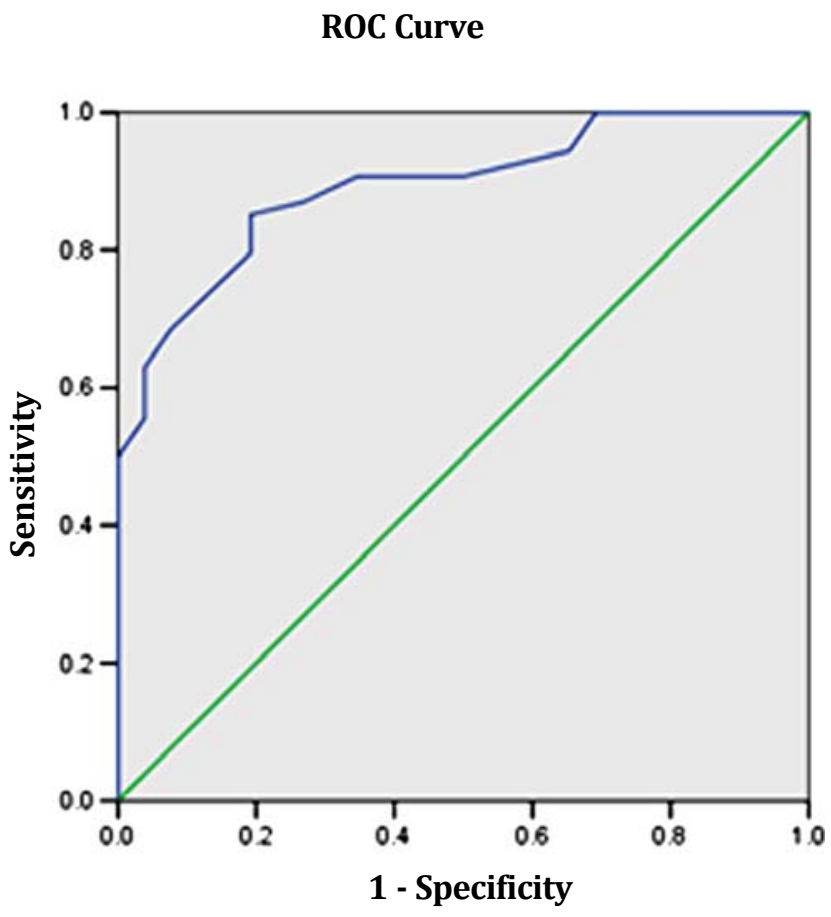

Figure 1. Receiver-operator characteristic (ROC) curve

\section{DISCUSSION}

The findings of this study demonstrate that $75.4 \%$ of women with threatened preterm labor successfully continued their pregnancy for more than 24 hours. Cut off point of cervical length in this study was $2.65 \mathrm{~cm}$ with sensitivity $94.4 \%$ and specificity 65.4\%. Delivery within 24 hours occurred in 9 women with cervical length $\leq 2.65 \mathrm{~cm}$.

There are four previous studies examining ultrasonographic measurement of cervical length at the time of admission, in women presenting with threatened preterm labor. ${ }^{5-13}$ Iams et al examined 60 women presenting at 24-35 weeks and reported that the mean of cervical length of those delivering preterm labor was shorter than those delivering at term, with the cut off point of cervical length of 3 $\mathrm{cm}$. Similarly, a study of 76 women presenting at 24-36 weeks reported that the cut off point of cervical length in successfully prolonged pregnancy was $2.6 \mathrm{~cm}$.

Our finding that the odds ratio for delivering preterm labor in women with cervical length less than $2.65 \mathrm{~cm}$ was 13.76 suggest that shorter cervical length examined with transvaginal scan could be used to predict the actual occurrence of preterm delivery in patients with threatened preterm labor.

\section{CONCLUSSION}

This study found that the cut off point of cervical length in threatened preterm labor was $2.65 \mathrm{~cm}$. There was significant relationship between the cervical length and the incidence of preterm labor. We suggest that cervical length assessment with transvaginal scan should be used as routine procedure to predict the chance of preterm delivery in patients with threatened preterm labor.

\section{REFERENCES}

1. Carey AJ, Gibbs RS. Preterm labor and post-term delivery. In: Gibbs RS, Karlan BY, Haney AF, Nygaard IE, eds. Danforth's obstetrics and gynecology. $10^{\text {th }}$ ed. Philadelphia: Lippincott William and Wilkins. 2003; 11: 165-85

2. Berghella V, Bega G. Ultrasound evaluation of the cervix. In: Callen PW, ed. Ultrasonography in obstetrics and gynecology. $5^{\text {th }}$ ed. Philadelphia: Saunders. 2008; 18: 699-718

3. Hui D, Liu G, Kavuma E, Hewson SA, McKay D, Hannah ME. Preterm labour and birth: a survey of clinical practice regarding use of tocolytics, antenatal corticosteroid and progesterone. JOGC. 2007: 117-24

4. Ogle R, Hyett J. Screening for spontaneous preterm labor and delivery. In: High risk pregnancy. $3^{\text {rd }}$ ed. Philadelphia: Saunders. 2005: 1293-1329 
5. Iams JD. Prediction and early detection of preterm labor. AJOG. 2003; 10(2): 402-12

6. Iams JD, Goldenberg RL, Meis PJ, Mercer BM, Moawad AH, Das A. The length of the cervix and the risk of spontaneous premature delivery. NEJM. 1996; 334(9): 567-72

7. Tsoi E, Akmal S, Rane S, Otigbah C, Nicolaides KH. Ultrasound assessment of cervical length in threatened preterm labor. Ultrasound Obstet Gynecol. 2003; 21: 552-55

8. Iams JD, Paraskos J, Landon MB, Teteris JN, Johnson FF. Cervical sonography in preterm labor. Obstet Gynecol. 1994; 84: 40-6

9. Lim K, Butt K, Crane JM. Ultrasonographic cervical length assessment in predicting pretem birth in singleton pregnancies. Clinical Practice Guideline. JOGC. 2011
10. Rozenberg P, Goffinet F, Malagrida L, Giudicelli Y, Perdu M, Houssin I. Evaluating the risk of preterm delivery: a comparison of fetal fibronectin and transvaginal ultrasonographic measurement of cervical length. AJOG. 1997; 176(1): 196-9

11. Van de Hof M, Crane J. Ultrasound cervical assessment in predicting preterm birth. Clinical Practice Guideline. SOGC. 2001

12. Leitich H, Brunbauser M, Kaider A, Egarter C, Husslein P. Cervical length and dilatation of the internal cervical os detected by vaginal ultrasonography as markers for preterm delivery: a systematic review. AJOG. 1999; 181(6): 1465-72

13. Goldberg J, Newman RB, Iams JD, Meiss PJ, Mercer BM, Moawad AH. Preterm prediction study. AJOG. 2008; 112(3): 508-15 